\title{
Evaluation of watershed carrying capacity for watershed management (a case study on Bodri watershed, Central Java, Indonesia)
}

\author{
Ignatius Sriyana ${ }^{1, *}$ \\ ${ }^{1}$ Civil Department, Faculty of Engineering, Diponegoro University, Semarang, Indonesia
}

\begin{abstract}
Excessive land use without any concern towards land and water conservation codes of conduct has a great potential to cause inevitable erosion and sedimentation, flood, drought, and decrease in vegetation coverage and accelerated land degradation, leading to change in watershed carrying capacity. This study aimed at evaluating the watershed classification, dealing with its carrying capacity, which is fundamental for planning in the watershed management. During the research, the author performed field surveys, questioner dissemination, and laboratory tests for suspended sediment quality. Data collected during the observation were subject to further analysis under five predetermined criteria. The study found that the Bodri Watershed carrying capacity was at 96.7, covering percentage of critical land, percentage of vegetation coverage, erosion index scored 10, respectively. The classification for the Bodri Watershed according to carrying capacity was considered moderate and classified as "to be improved" instead of "to be maintained".
\end{abstract}

\section{Introduction}

Watershed Management is a human action aimed at ensuring the use of watershed resources, through an integrated ecosystem approach [1], to maintain the sustainability of existing resources within the watershed by conserving well-balanced quantities of water, soil, vegetation, and other natural resources [2], thereby reducing or avoiding negative impacts downstream [3]. This is an effort to maintain the health of the watershed.

A healthy watershed area is a watershed that has the ability to provide the needs of all ecosystems [4], used as a measure of how well resource management activities are able to balance anthropogenic needs, ecological functions, and integrity within the watershed. To know the condition of watershed health, it is necessary to carry out evaluations and to monitor watershed management activities. It is important to monitor continuous changes of the implementations carried out there to see the progress compared to the targeted goal [5]. Furthermore, evaluation and monitoring activities measure whether the watershed management has been implemented successfully or less successfully against existing watershed condition targets or standards [1], and the results should be reported to assist in guiding decisions on sustainable implementation [6].

* Corresponding author: sriyana@live.undip.ac.id 
Bodri Watershed is one of 108 watersheds under priority in Indonesia due to its critical status. The watershed has been suffering a decline of ecosystem and environmental quality [7]. The decline of environmental quality is due to limited conservation forest area $(3.7 \%$ of the total area) and production forest (19.86\% of the total area). Plantation and bushes and marsh have become the dominating feature (36\% of the total area), leaving only $16.7 \%$ of the area for rice field. To make matters worse, population stress has also been higher than ever before, floods become more apparent during the rainy season (so does the drought during the dry season), and a higher rate of erosion and sedimentation. Such conditions indicate that the carrying capacity of Bodri Watershed is declining, causing problems for economic life. Therefore, an improvement must be made available $[8,9]$. Efforts should be taken as a feedback action as nature has provided humans with everything towards sustainable watershed management $[9,10]$. The watershed approach has been considered an appropriate analysis towards water resources planning and management problem-solving $[9,11-12]$. One of efforts is by performing an evaluation of the watershed classification according to its carrying capacity $[13,14]$. The watershed classification is not intended to determine the technical guidance for forest and land rehabilitation as well as water resources management. Instead, it provides an illustration of the urgency for watershed management [13].

This study aimed at evaluating the watershed classification dealing with its carrying capacity, which is fundamental for planning in the watershed management.

\section{Method of data collection and analysis}

\subsection{Study area}

Bodri Watershed is situated on the coordinates of $109^{\circ} 09^{\prime} 00^{\prime \prime}-109^{\circ} 15^{\prime} 31^{\prime \prime}$ East and $06^{\circ} 51^{\prime} 47^{\prime \prime}-07^{\circ} 04^{\prime} 29^{\prime \prime}$ South. It covers a total area of $65,248.54$ hectares $(2.6 \%$ of the total area of BPDAS Pemali Jratun) and a total radius area of $599.90 \mathrm{~km}^{2}$. The major upstream river of the Bodri Watershed is the 87-kilometer long (Fig.1).

\subsection{Sampling technique}

Instruments used during the research observation consisted of: a Watershed Surveillance Station for collecting hydrological data; Global Positioning System (GPS), for determining geographical coordinate points where samples were collected; digital camera, for on site documentation; ArcView software, for landsat imaging and digital maps interpretation; and, a set of computers, for data processing and analysis.

During surveying and data collection the study made use of the following equipment: land coverage maps, land use/data maps, watershed/sub-watershed maps (i.e., watershed/sub-watershed, river, land and topography/contour), administrative maps, land capacity class maps, and hydrological data (on debit, rainfall, sediment, and surface runoff). 


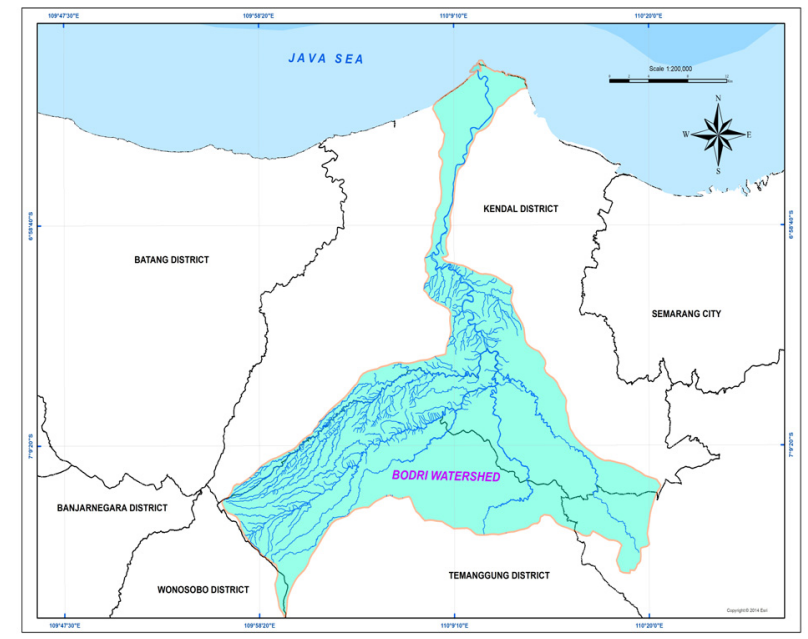

Fig. 1. Study area, Bodri Watershed.

\subsection{Technique of data analysis}

Data processing was performed in several stages, as follows: data collection, data selection, and data tabulation. All data were tabulated according to land (critical land, vegetation covering, and land appropriateness) and hydrology (debit, rainfall, and sediment). The field observation was done in concert with related institutions (Local Development Planning Board, Municipal Office of Public Works for water resources and spatial management, Municipal Office of Environment, Provincial Office of Environment and Forestry, Centre for Statistics on Population and Citizenship Records, and Municipal Office of Social Affairs) of Temanggung and Kendal Regencies. The data analysis for evaluating the watershed carrying capacity was performed using Microsoft Office Excel, covering five criteria of land use, water management, socio-economic aspect, building investment, and area spatial use. The watershed classification was evaluated according to the ongoing standard [7] and carrying capacity to determine the priority scale.

\section{Criteria/sub-criteria of Bodri watershed carrying capacity}

The five-stage integrated evaluation of the Bodri Watershed carrying capacity was performed to find out the criteria according to land condition, water management, socieconomic aspect, building investment, and area spatial use. The carrying capacity evaluation for each criterions/sub-criterion [14-16] indicated as follows.

\subsection{Land condition}

\subsubsection{Critical area percentage}

The critical area percentage was determined according to the data analysis for the critical land [15] and subject to an onsite ground check for updated and existing result, in which only those with critical and severely critical conditions were included. The critical area of Bodri Watershed covered 6,245.46 ha (or 6.34\% of the total area 65,248.54 ha). It indicated that the critical area at Bodri Watershed fell into the Low classification (relatively good). 
The critical area had a major impact on the Bodri River Stream because it had a weight score of $20 \%$. The critical area is defined as an area suffering from damage, causing loss of function to the expected limit [16]. In conclusion, the areas surrounding Bodri Watershed remained highly productive with a strong carrying capacity to provide the maximum results using appropriate land and area management techniques.

\subsubsection{Vegetation covering percentage}

The percentage followed the requirement of Directorate General of Planology of the Ministry of Forestry [17] and was subject to an onsite ground check. The vegetation covering of Bodri Watershed had a total permanent vegetated area of 6,783 ha $(39.28 \%$ of the total area). In other words, it was classified as Poor. These data concluded that the watershed lacked permanent vegetation due to changes in land function, i.e. for seasonal cultivated crops or other purposes. A good watershed must have the vegetation covering index of $>70 \%$.

\subsubsection{Erosion index}

In terms of erosion index, which deals with the vegetation management and conservation treatment, Bodri Watershed had an erosion index of 0.38 or IE $<0.5$. In other words, it was classified as Moderate. Such conditions indicated that the area was simultaneously managed but in a very conventional manner and hereditary, in which the techniques were surpassed through generations. The land conservation treatment such as terrace and SPA only applied to technical and wet rice fields, whereas dry rice fields were excluded. The crop pattern management took place by season and agricultural life and management remained traditional and local. Furthermore, older generations dominated the agricultural activities due to lack of interest from the younger generations.

\subsection{Water management}

\subsubsection{Stream regime coefficient}

Stream regime coefficient is a Q max-Q min ratio obtained from SPAS. The KRA score for Bodri Watershed was 215.22, included in a High classification (KRA > 110). In other words, this watershed had a quite unstable stream (flooding during rainy season; low water debit during dry season). The watershed storages were not quite capable of storing the rain water into the ground, causing floods. Therefore, during the dry season the storage could not afford to supply the water.

\subsubsection{Annual stream coefficient}

The annual stream coefficient of the watershed affects the rainfall used for water storage and water supply. The high annual stream coefficient indicates a poor capacity of the watershed to absorb the rain water into the ground due to poor vegetation coverage, steep slope, soil type, and land conservation treatment. Bodri Watershed had annual stream coefficient of 0.1 , classified as Low. However, its stream regime coefficient was considered High, indicating that the rain water absorbed into the ground was not stored due to steep slope at the river downstream. Putih and Lutut, sub-downstream areas, had a grumusol soil characteristic, which was not responsive to erosion and not capable of storing the water because it is composed of limestones. 


\subsubsection{Sediment content}

A good sedimentation occurs in areas or branches of the main river due to soil deposits from erosion and sedimentation. The sediment content of Bodri Watershed was calculated using a USLE equation by determining A score (erosion alert) of each area unit of the watershed multiplied by SDR. The sediment of the watershed obtained was 24.37 (classified High because it was higher than 20). This high sediment caused the loss of soil layers. The major causes of the sedimentation were poor vegetation covering and plain slope at the river downstream, as well as poor conservation treatment and change in land use at the river downstream. The high sedimentation rates were evident at Lutut (61.17) and Loging (44.2) sub-watersheds. These two sub-watersheds had their upstream in Temanggung Regency.

\subsubsection{Floods}

Floods occurred at all sub-watersheds with a frequency of twice annually (even four times in extreme conditions). The floods did not only occur at the major rivers, but also at the sub-upstream. They could have been accommodated by the river trenches, but not every river had such capacity. The historical records indicate that the worst River Bodri occurred in 2009 at the expense of local population and agricultural area in Pidodo Kulon and Pidodo Wetan Villages. River Lutut, River Putih, and River Logung, all were situated at the river upstream and wide and deep enough to supply and store the water, preventing the worsening floods. The extreme gradient of the river helped its stable water flow.

\subsubsection{Water use index}

The water index use of Bodri Watershed was $564(<1,700)$, classified severely Poor. The water indices of each sub-watershed were also poor $(<1,700)$. The very low water index indicates an inability to supply the water for irrigation or daily needs, i.e. drinking water, especially during the dry season. Artificial ponds, folders, or lakes are necessary to supply the water and to prevent the floods. As of the research period, there were only a few water ponds provided by PT Zanzibar.

However, Logung sub-watershed had the water index of 2,257 (>1,700). The area was very fertile and covered Kaloran and Candiroto Districts. The study found 18 water supplies and storages in virgin forests, preventing the area from flooding during the rainy season and droughts during the dry season.

\subsection{Socio-economic aspect}

\subsubsection{Population stress}

The population stress of Bodri Watershed was relatively high $(>2)$. Such a condition was found in all, but Bodri downstream, sub-watersheds. The Bodri downstream had a population stress of $1.43(<2)$, whereas the population stress of Bodri Watershed was 2.16. Such conditions indicated that the local population greatly depended on the land sector to fulfil their daily living. The high population stress caused the land to be occupied simultaneously to produce. They did not give spare time for the land except during the dry season. Accordingly, the land became less fertile. Plants once cultivated by their ancestors, e.g. rosella and orok-orok, were no longer found. Inorganic fertilizers had dominated the agricultural activities, damaging soil structures due to excessive chemical contents. 
Conversely, Bodri downstream remained intact with the population stress of $>2$, in which $75 \%$ of the total area was plain and urban. The settlements grew quickly as the population grew in numbers. The low population stress indicated that at Bodri downstream the population did not only rely on the land sector. Instead, in this area there had been factories, offices, stores, and markets for alternative living of the local people. In addition, they also run service businesses.

\subsubsection{Welfare}

Population welfare is characterized by the high (or low) poverty rate at the watershed. The field observation found that the population welfare was high (poor) $>30$. Of 744,465 populations, $30.2 \%$ of them were still under the poverty line. Of three sub-watersheds at Bodri Watershed, Putih sub-watershed had the highest welfare $(23.3 \%)$. It was due to its natural condition. Putih sub-watershed has the upstream areas of the Kaloran, Limbangan, Sukorejo, and Sumowono Districts. The road access in these areas was poor, made of combined concrete-macadam pavements. The poor road access did not necessarily mean that these areas were poorly treated by the local governments. Instead, it was due to harsh natural conditions. Distance from urban area, topography, and soil structure contributed to the damage of the road access, as the study found in the Limbangan-Kedungboto-Cening route.

\subsubsection{Law enforcement}

Law enforcement in land management closely relates to local culture. The rule of law is drafted to provide written terms and conditions towards the peoples' treatment of the land and water conservation. The study did not find any rule of law enforced in the area of Bodri River Stream. Should there be any, it had not been put into practice. Interviews with village staff and officers revealed that they had already had a rule of law but it remained ineffective. However, in absence of written rule, the local people had already understood the benefit of planting trees, constructing terraces, and performing land conservation. Gotong royong (mutual work for mutual interest) has become the local code of conduct that was passed through generations. Gotong royong became the principle of problem-solving of the localities.

\subsection{Building investment}

\subsubsection{Urban classification}

Bodri Watershed covered four regencies, i.e. Temanggung, Kendal, Semarang, and Wonosobo. The urban classification was approached by population size and area within the watershed. The data analysis concluded that urban areas within Bodri Watershed were classified as Moderate. Whereas the cumulative score was classified Large.

\subsubsection{Building investment value}

The data analysis revealed that at Bodri Watershed there were several vital buildings necessary to be protected. They had been shortlisted, including large water dams with irrigation branches of 104 smaller dams and a larger dam. Government office buildings were also under inventory, as well as large factories. The investment value was estimated at more than 60 billion of Rupiah. 


\subsection{Area spatial use}

\subsubsection{Conservation area}

The data analysis resulted in, as follows: 7,385.04 ha (11.31\% of the total area) consisted of conservation area with $3,361.04$ ha $(45.51 \%$ of the total area) with vegetation covering classified as Good. The vegetation covering within the conservation area in the Watershed is expected to be $>70 \%$. The establishment of conservation area is based on physical characteristics of the area and a role in creating balanced water management, especially for Bodri Watershed. The conservation area also plays a significant role in storing and supplying the water for the watershed.

\subsubsection{Cultivated area}

Cultivated areas at Bodri Watershed on the slope classed as $0-25 \%$ was $40,689.45$ ha $(70.32 \%)$. These data revealed that the cultivated area had been adequate. Cultivated area for seasonal crops/settlements was determined by a land unit with the slope of 8 per cent at the maximum rate with soils not prone to erosion. The land unit with the slope class of 8-5 per cent with soils not prone to erosion, and slope class of 15-25 per cent with soils slightly prone to erosion. Dry areas dominated the composition of the cultivated area of the watershed. Management is necessary to anticipate problems related to water absorption, urban green area, water use management and groundwater intake, and urban area development, to mention some.

\section{Bodri watershed carrying capacity}

The evaluation of the watershed carrying capacity was performed in an integrated manner covering five criteria as follows: land condition $40 \%$; water management condition $20 \%$; socio-economic condition $20 \%$; building investment condition $10 \%$; and area spatial use condition $10 \%$. The scores of the carrying capacity of the watershed were obtained from data analysis of each weight score of indicators and their parameters. The end result of the evaluation of the watershed carrying capacity was obtained by combining the value and the weight of each parameter [14], as shown in Figure 2 and Table 1.

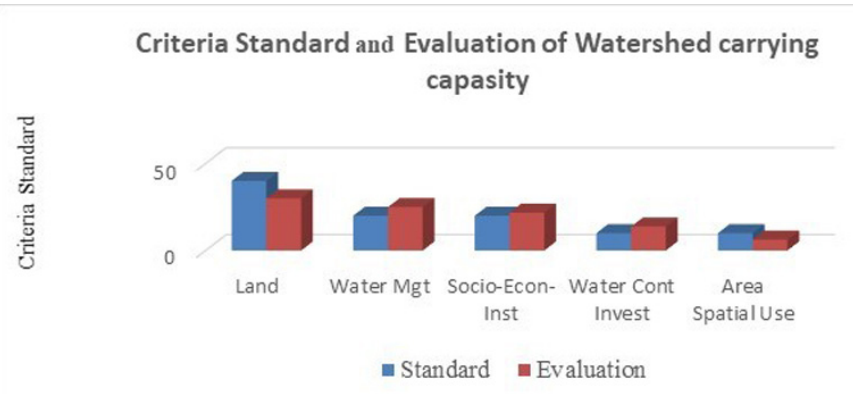

Fig. 2. Criteria standard and evaluation of watershed carrying capacity. 
Table 1. Bodri watershed carrying capacity.

\begin{tabular}{|c|c|c|c|c|c|c|c|}
\hline No & $\begin{array}{l}\text { Criteria/Sub- } \\
\text { criteria }\end{array}$ & $\begin{array}{c}\text { Weight } \\
\%\end{array}$ & Fact Value & Value & Class & Score & $\begin{array}{l}\text { Result } \\
(3 \times 7)\end{array}$ \\
\hline 1 & 2 & 3 & 4 & 5 & 6 & 7 & 8 \\
\hline \multirow[t]{4}{*}{1} & Area condition & 40 & & & & & \\
\hline & $\begin{array}{l}\text { 1.Critical area } \\
\text { percentage }\end{array}$ & 20 & $3.60 \%$ & $\begin{array}{c}\text { PPLK } \\
\leq 5\end{array}$ & $\begin{array}{l}\text { Very } \\
\text { Low }\end{array}$ & 0.5 & 10 \\
\hline & $\begin{array}{l}\text { 2.Vegetation } \\
\text { covering }\end{array}$ & 10 & $43.19 \%$ & $\begin{array}{c}40< \\
\mathrm{PPV} \leq \\
60\end{array}$ & Moderate & 1 & 10 \\
\hline & 3.Erosion Index & 10 & $0.38 \%$ & $\mathrm{IE}<0.5$ & Moderate & 1 & 10 \\
\hline \multirow[t]{6}{*}{2} & $\begin{array}{l}\text { Water management } \\
\text { condition }\end{array}$ & 20 & & & & & \\
\hline & $\begin{array}{l}\text { 1.Stream regime } \\
\text { coefficient (KRA) }\end{array}$ & 5 & 215.22 & $\begin{array}{l}\text { KRA } \\
>110 \\
\end{array}$ & $\begin{array}{l}\text { Very } \\
\text { High }\end{array}$ & 1.5 & 7.5 \\
\hline & $\begin{array}{l}\text { 2.Annual stream } \\
\text { coefficient (KAT) }\end{array}$ & 5 & 0.1 & $\begin{array}{c}\mathrm{KAT} \\
0.2 \\
\end{array}$ & $\begin{array}{l}\text { Very } \\
\text { Low }\end{array}$ & 0.5 & 2.5 \\
\hline & $\begin{array}{l}\text { 3.Sediment content } \\
\text { (MS) }\end{array}$ & 4 & 24.37 & $\mathrm{MS}>20$ & $\begin{array}{l}\text { Very } \\
\text { High }\end{array}$ & 1.5 & 6 \\
\hline & 4.Flood & 2 & $>2$ times & $>1$ time & $\begin{array}{l}\text { Very } \\
\text { High }\end{array}$ & 1.5 & 3 \\
\hline & $\begin{array}{l}\text { 5.Water use index } \\
\text { (IPA) }\end{array}$ & 4 & 564 & $\begin{array}{l}\mathrm{IPA} \leq \\
1,700\end{array}$ & $\begin{array}{l}\text { Very } \\
\text { Poor }\end{array}$ & 1.5 . & 6 \\
\hline \multirow[t]{4}{*}{3} & $\begin{array}{l}\text { Socio-economic } \\
\text { condition }\end{array}$ & 20 & & & & & \\
\hline & $\begin{array}{l}\text { 1.Population stress } \\
\text { (IKL) }\end{array}$ & 10 & 2.16 & $\begin{array}{c}2.0<\mathrm{IKL} \\
\leq 4.0\end{array}$ & High & 0.75 & 7.5 \\
\hline & $\begin{array}{l}\text { 2.Population } \\
\text { welfare (TKP) }\end{array}$ & 7 & 30.2 & $\begin{array}{l}\text { TKP } \\
>30\end{array}$ & $\begin{array}{l}\text { Very } \\
\text { Poor }\end{array}$ & 1.5 & 10.5 \\
\hline & 3.Law enforcement & 3 & $\mathrm{n} / \mathrm{a}$ & $\mathrm{n} / \mathrm{a}$ & Poor & 1.25 & 3.75 \\
\hline \multirow[t]{3}{*}{4} & Building investment & 10 & & & & & \\
\hline & $\begin{array}{l}\text { 1.Urban } \\
\text { classification }\end{array}$ & 5 & 744.94 & $>5 \times 10^{5}$ & High & 1.25 & 6.25 \\
\hline & $\begin{array}{l}\text { 2. Water } \\
\text { construction } \\
\text { classification }\end{array}$ & 5 & $1,185,735,400$ & $\begin{array}{c}\text { IBA } \\
>6 \times 10^{10}\end{array}$ & $\begin{array}{l}\text { Very } \\
\text { High }\end{array}$ & 1.5 & 7.5 \\
\hline \multirow[t]{4}{*}{5} & Area spatial use & 10 & & & & & \\
\hline & 1.Conservation area & 5 & $45.51 \%$ & $\begin{array}{c}45 \\
<\mathrm{KL} \leq 70\end{array}$ & Good & 0.75 & 3.75 \\
\hline & 2.Cultivated area & 5 & $70.32 \%$ & $\mathrm{~KB}>70$ & $\begin{array}{l}\text { Very } \\
\text { Low }\end{array}$ & 0.5 & 2.5 \\
\hline & $\begin{array}{l}\text { Bodri Watershed } \\
\text { Performance }\end{array}$ & & & & & & 96.7 \\
\hline
\end{tabular}

The evaluation of the watershed carrying capacity is considered Very Good when the score is $<70$; Good when the score is between $>70$ and $<90$; Moderate when the score is between $>90$ and $<100$; Poor when the score is between $>100$ and $<130$; and Very Poor when the score is $>130[13,14]$. Whereas, the evaluation of the watershed classification according to carrying capacity consists of two classifications, i.e. maintained classification (carrying capacity $<100$; good-very good) and restored classification (carrying capacity $>$ 100; poor-very poor) [13]. 
According to the data analysis the carrying capacity of Bodri Watershed was 96.7. In other words, the watershed was classified as moderate and maintained. Therefore, it had not agreed with the existing condition. By increasing the carrying capacity into moderate $(>90$ t0 $<110$ ), the classification improved. Therefore, the classification of the carrying capacity of Bodri Watershed was considered as moderate and "to be improved" not "to be maintained" (Fig. 3).

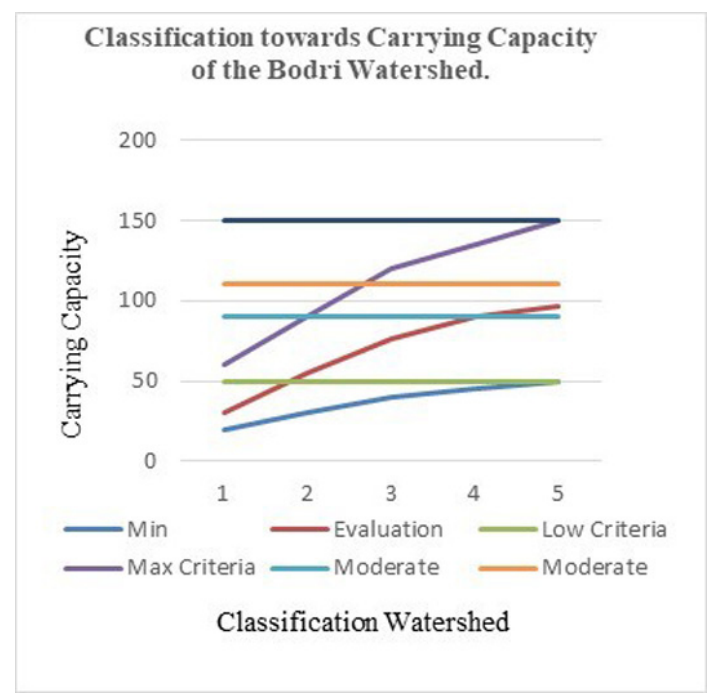

Fig. 3. Classification of carrying capacity of the Bodri Watershed.

\section{Conclusions}

Bodri Watershed covers 65,248.54 ha area, 25 districts, and 203 villages. It is divided into three sub-watersheds, i.e. Bodri Downstream (25,364.98 ha), Logung sub-watershed (8.921.10 ha), Lutut sub-watershed (18,411.19 ha), and Putih sub-watershed (12,551.28 ha).

The carrying capacity of Bodri Watershed was found to be 96.7, consisting of, as follows: land condition criteria (critical area, vegetation covering, and erosion index) with a score of 10 each, making a total score of 30; water management (stream regime coefficient 7.5 , annual stream coefficient 2.5 , sediment content 6 , floods 3 , water use index 6 ), making a total score of 25; socio-economic condition (population stress 7.5 , population welfare 10.5, law enforcement 3.75), making a total of 21.5; building investment (urban classification 6.25, building value 7.5), making a total score of 13.75; and area spatial use (conservation area 3.75, cultural area 2.5), making a total score of 6.25.

The evaluation of Bodri Watershed resulted in a moderate carrying capacity and maintained classification. This evaluation did not apply to the existing conditions. Using the moderate carrying capacity $(>90$ to $<110$ ), with improved classification, the Bodri Watershed classification was considered moderate, and "to be improved" not "to be maintained".

The author is indebted to Balai Pengelolaan Daerah Aliran Sungai Pemali Jratun, Jawa Tengah, and Water Resources Laboratory, Civil Engineering, Faculty of Engineering, Diponegoro University, Prof. H. Soedarto, SH Street, Tembalang Campus, Semarang, Jawa Tengah, Indonesia for allowing the author to use the facilities of the laboratory. 


\section{References}

1. FAO, Watershed management in action - lessons learned from FAO field projects (Rome, 2017).

2. S. R. Ahn and S. J. Kim, Assessment of Integrated Watershed Health Based on The Natural Environment, Hydrology, Water Quality, and Aquatic Ecology, Hydrol. Earth Syst. Sci. 21, 5583-5602 (2017)

3. S. Darghouth, C. Ward, G. Gambarelli, E. Styger, J. Roux, Watershed Management Approaches, Policies and Operations: Lessons for Scaling Up, Water Sect. Board Discuss. 11 (World Bank, Washington D.C., 2008)

4. U.S. EPA, Healthy Watersheds Initiative: National Framework and Action Plan. EPA 841-R-11-005 (U.S. Environmental Protection Agency, Office of Water, Washington D.C., 2011).

5. C. Jones, R. M. Palmer, S. Motkaluk, M. Walters, Watershed Health Monitoring Emerging Technologies (Lewis Publishers: A CRC Press Company, Boca Raton, London, New York, Washington D.C., 2002)

6. U.S. EPA, Watershed Approach Frame Work (U.S. Environmental Protection Agency, Washington, D. C., 1996)

7. Keputusan Menteri Kehutanan Republik Indonesia Nomor: Sk. 328/Menhut-Ii/2009 Tentang Penetapan Daerah Aliran Sungai (DAS) Prioritas (in Indonesian)

8. UU No. 41 Tahun 1999 tentang Kehutanan (in Indonesian)

9. D. C. Mckinney, X. Cai, M. W. Rosegrant, C. Ringler, C. A. Scott, Modelling Water Resources Management at The Basin Level: Review and Future Directions, Internat. Water Mgmt. Inst., SWIM Paper 6 (1999)

10. Undang-Undang Republik Indonesia Nomor 37 Tahun 2014 Tentang Konservasi Tanah Dan Air (in Indonesian)

11. A. Mirchi, D. Watkins, K. Madani (Ed: J. C. Vaughn), Modeling For Watershed Planning, Management, And Decision Making, Watersheds: Mgmt., Restor. And Enviro. ISBN: 978-1-61668-667-3 (Nova Science Publishers, Inc, 2009)

12. Peraturan Pemerintah Nomor 37 Tahun 2012, Tentang Pengelolaan Daerah Aliran Sungai (in Indonesian)

13. Peraturan Menteri Kehutanan Republik Indonesia Nomor: P. 60 /Menhut-II/2014, tentang Kriteria Penetapan Klasifikasi Daerah Aliran Sungai (in Indonesian)

14. Peraturan Menteri Kehutanan Republik Indonesia Nomor: P. 61 /Menhut-II/2014 tentang Monitoring Dan Evaluasi Pengelolaan Daerah Aliran Sungai (in Indonesian)

15. Peraturan Direktur Jenderal Bina Pengelolaan Daerah Aliran Sungai Dan Perhutanan SosiaL Nomor: P. 4/V-Set/2013Tentang Petunjuk Teknis Penyusunan Data Spasial Lahan Kritis (in Indonesian)

16. SK Dirjen RRL No. 041/Kpts/V/1998 tanggal 21 April 1998 tentang Kriteria Lahan Kritis (in Indonesian)

17. Direktorat Jenderal Planologi Kehutanan, Peta Penutupan Lahan (Kementerian Kehutanan, 2012) (in Indonesian) 